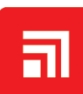 CHITKARA \\ Journal of Nuclear Physics, Material Sciences, Radiation and Applications \\ Journal homepage: https://jnp.chitkara.edu.in/
}

\section{Radon Dose Determination and Radiological Risk in Some Mexican Caves with CR-39 Detectors}

\author{
A. Chavarria ${ }^{1 *}$ iD, J.I. Golzarri ${ }^{2}$ and G. Espinosa ${ }^{2}$ \\ ${ }^{1}$ Sciences Faculty, National Autonomous University of Mexico \\ ${ }^{2}$ Instituto de Física, Universidad Nacional Autónoma de México, Cd. de México 04520 México; Condensed Matter Department, \\ Physics Institute, National Autonomous University of Mexico
}

"acchs2002@yahoo.com.mx (Corresponding Author)

\section{ARTICLE INFORMATION}

Received: September 24, 2020

Accepted: January 25, 2021

Published Online: February 10, 2021

Keywords:

Caves, Radon, Doses, CR-39, Radiological risk

DOI: 10.15415 /jnp. 2021.82022

\section{ABSTRACT}

Radon $\left({ }^{222} \mathrm{Rn}\right)$ is a radioactive gas, from the ${ }^{238} \mathrm{U}$ decay chain, that contributes in large part of the natural radiation dose to which humans are exposed. Radon is the second cause of lung cancer after tobacco. The US-EPA considers a concentration of $148 \mathrm{~Bq} / \mathrm{m}^{3}$ for homes and $400 \mathrm{~Bq} / \mathrm{m}^{3}$ for workplaces as the reference level. Caves are closed spaces where ${ }^{222} \mathrm{Rn}$, which emanates from the surrounding minerals and rocks, can accumulate and reaches large concentrations that can represent a health risk for the guides, speleologists and visitors who spend time in these spaces. This work uses the previously recorded radon concentrations in 8 caves in Mexico and calculates the average dose range and the average annual dose for each of them with the "Wise" public domain program (http:// www.wise-uranium.org/rdcrn.html) to determine the level of radiological risk with 2,000 1,000 and 500 working hours per year. Karmidas cave had the highest average ${ }^{222} \mathrm{Rn}$ concentration with $27,633.3$ $\mathrm{Bq} / \mathrm{m} 3$ and for 2,000 working hours per year an average annual dose rate of $347.1 \mathrm{mSv} / \mathrm{y}$. Los Riscos cave had the lowest average concentration with $384.7 \mathrm{~Bq} / \mathrm{m}^{3}$ and for 2,000 working hours per year an average annual dose rate of $4.832 \mathrm{mSv} / \mathrm{y}$. These results show that all the caves studied present values, with 2,000 working hours per year, that exceed $3 \mathrm{mSv} / \mathrm{y}$ for workplaces and must be considered by the people who work in these places. A casual tourist visiting the caves does not present any radiological risk, while guides and speleologists should consider it.

\section{Introduction}

Radon $\left({ }^{222} \mathrm{Rn}\right)$ is a naturally occurring gas product of the decay of radium $\left({ }^{226} \mathrm{Ra}\right)$, it has a half-life of 3.8 days, is part of the uranium $\left({ }^{238} \mathrm{U}\right)$ decay chain and it is the main source of natural radiation to which the human being is exposed. According to the United States Environmental Protection Agency (US-EPA) and the World Health Organization (OMS) ${ }^{222} \mathrm{Rn}$ is the second cause of lung cancer after the Tabaco. In nature, ${ }^{222} \mathrm{Rn}$ emanates constantly from the soil and reaches concentrations of less than $50 \mathrm{~Bq} / \mathrm{m}^{3}$ [12] because it's constantly being diluted on atmosphere; however in closed spaces like caves or mines it can accumulate to reach concentrations of $\mathrm{KBq} / \mathrm{m}^{3}$ [1-6]. Caves are cavities that are formed in the interior of the earth due to different geological, chemical, volcanic, wave and wind processes and can extend up to several kilometers and reach great depths. These geological formations have been exploited by man throughout his history in many different ways, for example, they were used as housing by our ancestors approximately $5,00,000$ years ago [8]. Inside these places the ${ }^{222} \mathrm{Rn}$ concentrations may vary due to internal factors such as ventilation, types of surrounding minerals, length of the cave; also to external factors such as atmospheric conditions and geographical location [7].

Mexico is a country with around 7,000 caves in its territory [10] and many of them are a natural attraction for national and foreign visitors like Cacahuamilpa Caves, while others are frequented by speleologists and researchers, many of whom spend a lot of time inside them. Several studies have measured the concentration of ${ }^{222} \mathrm{Rn}$ inside caves in different countries such as Ireland [4], Slovenia [11], Hungary[13], Jamaica [9], Brazil [1], Ecuador [14] among others. In México Borau et al. (1993) measured ${ }^{222} \mathrm{Rn}$ concentration inside three caves located in the state of Guerrero. In another work Espinosa et al. (2008) determined the concentration of ${ }^{222} \mathrm{Rn}$ in a cave in the state of Oaxaca. Finally in 2013 Espinosa et al. measured the ${ }^{222} \mathrm{Rn}$ concentration in two caves in the state of Querétaro and two in the state of Puebla, where they also observed an interesting coincidence between ${ }^{222} \mathrm{Rn}$ concentrations and 
bat distribution; these animals are distributed in areas with medium and low gas concentrations.

Due to its effect on health, it is important to monitor the ${ }^{222} \mathrm{Rn}$ present in caves in order to know the radiological risk to which people who frequent these places may be exposed [1]. The main of this work is to calculate the dose of ${ }^{222} \mathrm{Rn}$, based on data previously collected and published in eight caves in the Mexican Republic to determine the radiological risk to which guides, speleologists who frequent these spaces may be exposed.

\section{Global Regulations and Action Levels}

Action levels and regulations for ${ }^{222} \mathrm{Rn}$ vary from country to country, e.g. in the United States indoor action levels are $148 \mathrm{~Bq} / \mathrm{m}^{3}$ in homes and $400 \mathrm{~Bq} / \mathrm{m}^{3}$ in workplaces [16]; in the United Kingdom workplace action levels are $400 \mathrm{~Bq} /$ $\mathrm{m}^{3}$ and dose limits are $5 \mathrm{mSv} /$ year. The European Union has action level ranges from $500 \mathrm{~Bq} / \mathrm{m}^{3}$ to $1,500 \mathrm{~Bq} / \mathrm{m}^{3}$ for workplaces. Mexico does not have regulations regarding radon levels in enclosed public and private spaces; for this reason, the regulations established by the US-EPA for intramural radon concentrations are taken into account.

\section{Methodology}

For this work the results of Borau et al. (1993) and Espinosa et al. (2008, 2013) were used. These authors used the technique of nuclear track in solids in CR-39 plastic $\left(\right.$ Lantrack $^{\oplus}$ ) detectors to measure the concentration of ${ }^{222} \mathrm{Rn}$ in eight caves in the Mexican Republic. This method is the most suitable for this type of environment since it is low cost, can be used for long periods of time, is not affected by environmental factors such as temperature and humidity, is easy to transport and handle, and has a high efficiency in the detection of alpha particles. Total exposure times for detectors inside the caves were between three and six months (Table 1). After being recovered, all plastics chemically etched in a thermo regulated bath. The tracks formed were counted and the ${ }^{222} \mathrm{Rn}$ concentrations were calculated for each cave.For more detailed description of the methodology consult Borau et al. (1993) and Espinosa et al. (2008, 2013).

\section{Caves Description}

Aguacachil cave is located in the state of Guerrero (Figure 1), at $18^{\circ} 35^{\prime} 30^{\prime \prime}$ north and $94^{\circ} 34^{\prime} 2^{\prime \prime}$ west, in a region with an altitude of $1,500 \mathrm{~m}$ above sea level. It has $1,618 \mathrm{~m}$ in its course, $169 \mathrm{~m}$ of maximum depth (Figure 2). Four sampling points were established where the CR-39 detectors were placed.

Las Pozas Azules are located in Acuitlapan, also in the state of Guerrero (Figure 1), at $18^{\circ} 37^{\prime} 26^{\prime \prime}$ north and $99^{\circ} 32^{\prime} 55.7^{\prime \prime}$ west. They have a length of $1,649 \mathrm{~m}$ and a depth of $197 \mathrm{~m}$ (Figure 2). Four sampling points were established in this cave where the CR-39 detectors were placed.

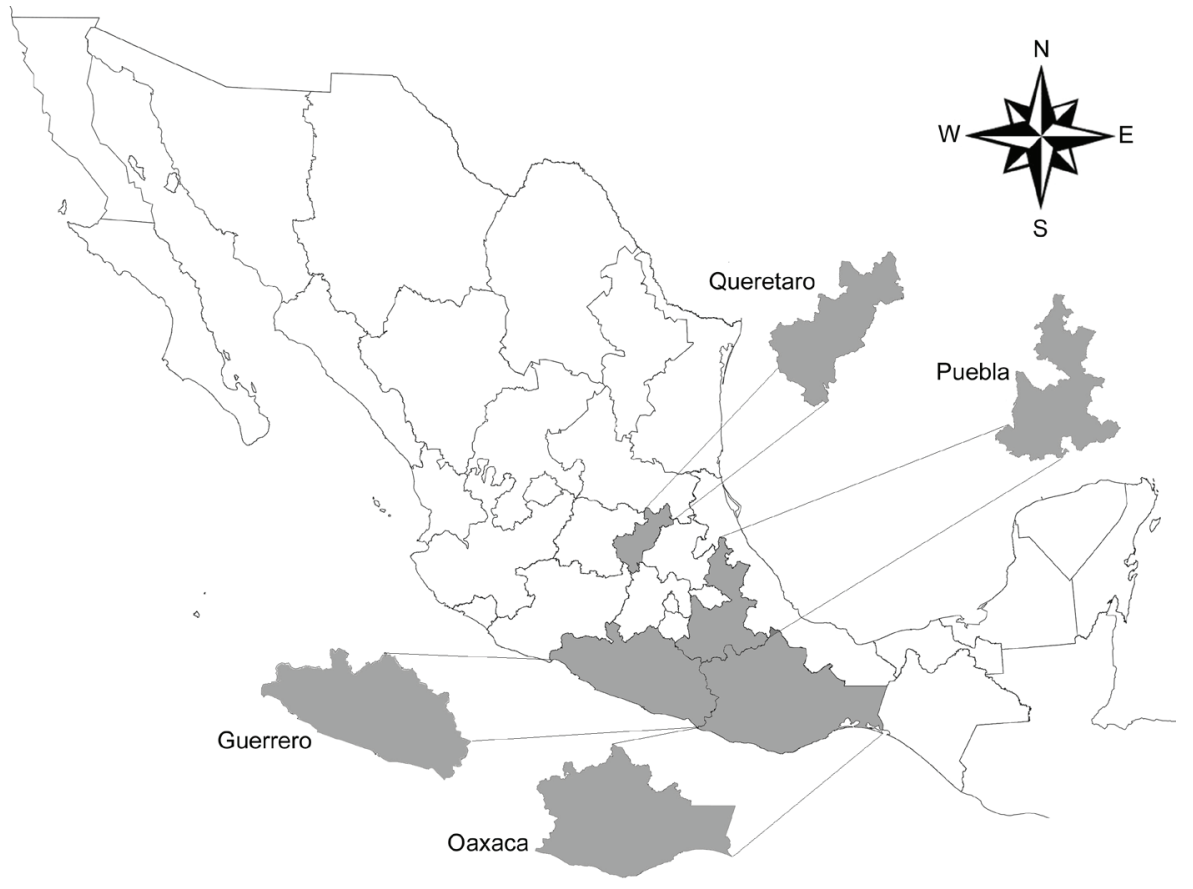

Figure 1: Location of the states where the studied caves are located. 
A
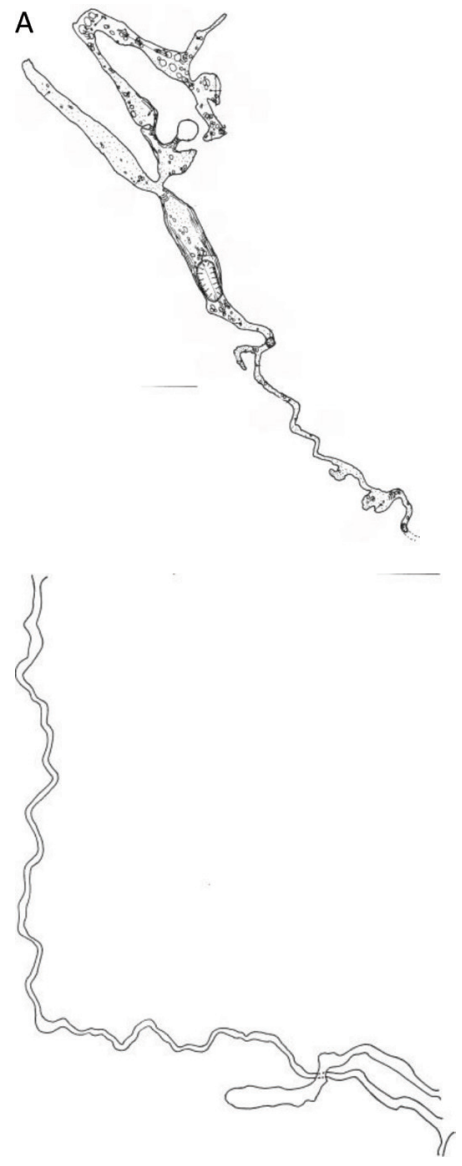

C

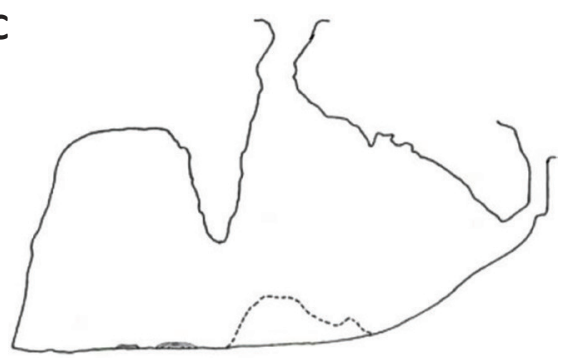

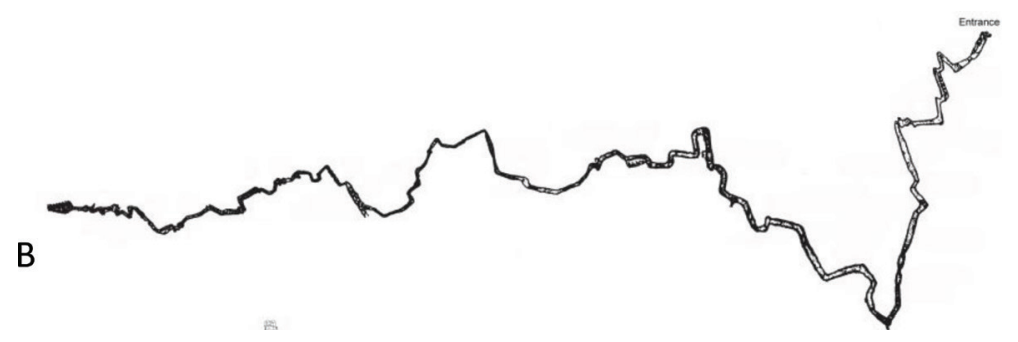
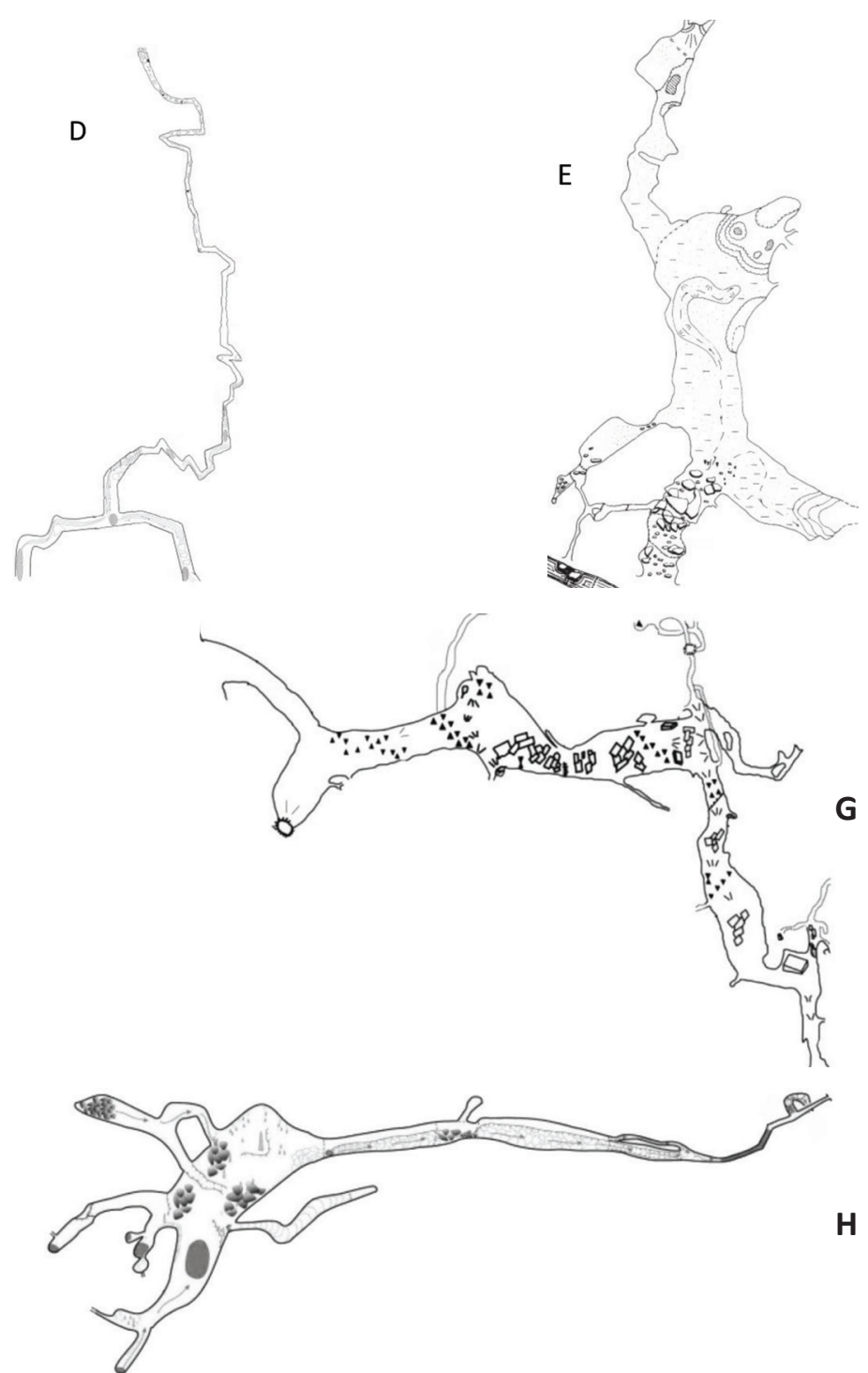

Figure 2: Studied caves. A.- Aguacachil, B.- Pozas Azules, C.- San Jeronimo, D.- Gabriel, E.- Los Riscos, F.- El Judío, G.- Coyozochico, H.- Karmidas. 
The San Jerónimo cave is located near Tenancingo, also in the state of Guerrero (Figure 1), at $18^{\circ} 40^{\prime} 11^{\prime \prime}$ north and $99^{\circ} 30^{\prime} 36^{\prime \prime}$ west. The San Jerónimo River runs through this place. Four sampling points were established where the CR39 detectors were placed. It is a space visited by tourists and speleologists who can take several hours to visit this cave (Figure 2).

Gabriel cave is located in the southern state of Oaxaca at $18^{\circ} 27^{\prime} 25^{\prime \prime}$ north and $96^{\circ} 40^{\prime} 34^{\prime \prime}$ west at an altitude of $110 \mathrm{~m}$ above sea level. The cave (Figure 2) is $1,500 \mathrm{~m}$ long, with a chimney $250 \mathrm{~m}$ from the entrance. Fifteen sampling points were established where CR-39 detectors were placed. The temperature average is $25.2^{\circ} \mathrm{C}$.

Los Riscos cave is located in the state of Querétaro (Figure 1) at $21^{\circ} 11^{\prime} 38^{\prime \prime}$ north and $99^{\circ} 30^{\prime} 50^{\prime \prime}$ west at an altitude of $1,122 \mathrm{~m}$ above sea level, with a length of 550 $\mathrm{m}$ and a depth of $39 \mathrm{~m}$ (Figure 2), an average temperature of $18^{\circ} \mathrm{C}$ and a relative humidity of $85 \%$. Twelve sampling points were established where the CR-39 detectors were placed.

El Judío cave, also located in the state of Querétaro (Figure 1), at $21^{\circ} 11^{\prime} 38^{\prime \prime}$ north and $99^{\circ} 30^{\prime} 50^{\prime \prime}$ west, is made of limestone, is $48 \mathrm{~m}$ long and $25 \mathrm{~m}$ deep, has two entrances, an interior temperature of $21^{\circ} \mathrm{C}$ and a relative humidity of $50 \%$ (Figure 2). Six sampling points were established where the CR-39 detectors were placed.

The Coyozochico cave is located in the Sierra Norte of the state of Puebla (Figure 1) at 19 $57^{\prime} 00^{\prime \prime}$ north and $97^{\circ} 24^{\prime} 36^{\prime}$ west. It has a length of $170 \mathrm{~m}$, an average temperature of $19^{\circ} \mathrm{C}, 68 \%$ relative humidity (Figure 2). Seven sampling points were established where CR-39 detectors were placed.

Karmidas Cave is located in the state of Puebla (Figure 1) at $19^{\circ} 58^{\prime} 10^{\prime \prime}$ north and $97^{\circ} 38^{\prime} 36^{\prime \prime}$ west. It is $260 \mathrm{~m}$ long (Figure 2), has an average temperature of $18^{\circ}$
$\mathrm{C}$ and $65 \%$ relative humidity. Nine sampling points were established where the CR-39 detectors were placed.

For more detail description of each caves consult Borau et al. (1993) and Espinosa et al. $(2008,2013)$.

The dose calculation for each sampling point of the areas studied was carried out using the public domain software "Wise" [17], to determine the radiological risk to which guides and speleologists who frequent these sites may be exposed. Three different times were considered for doses calculation: 2,000, 1,000 and 500 hours per year and an equilibrium factor of 0.4 was considered for ${ }^{222} \mathrm{Rn}$ and its children, since this is an average value among the values reported in the literature [15].

\section{Results and Discussion}

Table 1 summarizes the location, methodology and average ${ }^{222} \mathrm{Rn}$ concentration recorded in each of the eight caves studied. It can be seen that Karmidas cave in the state of Puebla has the highest concentration of ${ }^{222} \mathrm{Rn}(27633.3 \mathrm{~Bq} /$ $\mathrm{m}^{3}$ ), while Los Riscos in the state of Querétaro has the lowest $\left(384.7 \mathrm{~Bq} / \mathrm{m}^{3}\right)$. The variations in ${ }^{222} \mathrm{Rn}$ concentrations observed in Table 1 are related to the concentrations of ${ }^{238} \mathrm{U}$ and ${ }^{226} \mathrm{Ra}$ present in the minerals of each cave, rock porosity, the ventilation of the site which may be due to the presence of chimneys or the proximity to the cave entrance; the presence of rivers and water accumulation as well as the internal temperature of each cave and earthquakes are factors that affect the concentration of ${ }^{222} \mathrm{Rn}$ [3-5]. All these characteristics of each cave make them unpredictable and dynamic environments, which can be influenced by external factors such as rain, wind, altitude, atmospheric pressure and season. For this reason it is necessary to carry out constant measurements to better understand the dynamics of these environments.

Table 1: Caves studied and their general radon concentration.

\begin{tabular}{lcccc}
\hline \multicolumn{1}{c}{ Cave } & $\begin{array}{c}\text { Location } \\
\text { State }\end{array}$ & Methodology & $\begin{array}{c}\text { Time } \\
\text { Months }\end{array}$ & $\begin{array}{c}\text { 222 Rn Average } \\
\text { Concentration }\left(\mathbf{B q} / \mathbf{m}^{3}\right)\end{array}$ \\
\hline Aguacachil & Guerrero & Cr-39 & 3 & 1160 \\
Las Pozas Azules & Guerrero & Cr-39 & 3 & 1150 \\
San Jerónimo & Guerrero & Cr-39 & 3 & 1530 \\
Gabriel & Oaxaca & Cr-39 & 6 & 2500 \\
Los Riscos & Queretaro & Cr-39 & 6 & 384.7 \\
El Judío & Queretaro & Cr-39 & 6 & 471.6 \\
Coyozochico & Puebla & Cr-39 & 6 & 511.9 \\
Karmidas & Puebla & Cr-39 & & 27633.3
\end{tabular}


Table 2 lists the average dose rate and average annual dose rate values calculated with the "Wise" public domain software [17] and the average ${ }^{222} \mathrm{Rn}$ concentration in table 1 for the eight caves studied. With 2,000 working hours per year all caves exceeds the reference value of $3 \mathrm{mSv} / \mathrm{y}$ for workplaces; Karmidas cave has the highest value of annual dose rate $(347.1 \mathrm{mSv} / \mathrm{y})$ and Los Riscos cave has the lowest $(4.832 \mathrm{mSv} / \mathrm{y})$. A tourist guide or a speleologist who spends 2,000 hours in any of these caves should consider the radiological risk to which they are exposed.

Table 2: Average dose values and average annual dose for each sampling point in each cave and general average.

\begin{tabular}{|c|c|c|c|c|c|c|c|c|c|}
\hline Cave & $\begin{array}{c}\text { Occupancy } \\
\text { time (per } \\
\text { year) (h) }\end{array}$ & $\begin{array}{c}\text { Average } \\
\text { Dose } \\
\text { Rate } \\
\mu S v / h\end{array}$ & $\begin{array}{c}\text { Average } \\
\text { Annual } \\
\text { dose rate } \\
\mathrm{mSv} / \mathrm{y}\end{array}$ & $\begin{array}{c}\text { Occupancy } \\
\text { time (per } \\
\text { year) (h) }\end{array}$ & $\begin{array}{c}\text { Average } \\
\text { Dose } \\
\text { Rate } \\
\mu S v / h\end{array}$ & $\begin{array}{c}\text { Average } \\
\text { Annual } \\
\text { dose rate } \\
\text { mSv/y }\end{array}$ & $\begin{array}{c}\text { Occupancy } \\
\text { time (per } \\
\text { year) (h) }\end{array}$ & $\begin{array}{c}\text { Average } \\
\text { Dose } \\
\text { Rate } \\
\mu S v / h\end{array}$ & $\begin{array}{c}\text { Average } \\
\text { Annual } \\
\text { dose rate } \\
\mathrm{mSv} / \mathrm{y}\end{array}$ \\
\hline Aguacachil & 2,000 & 7.286 & 14.57 & 1,000 & 7.286 & 7.286 & 500 & 7.286 & 3.643 \\
\hline Las Pozas Azules & & 7.192 & 14.44 & & 7.192 & 7.192 & & 7.192 & 3.596 \\
\hline San Jerónimo & & 9.609 & 19.22 & & 9.609 & 9.609 & & 9.609 & 4.805 \\
\hline Gabriel & & 15.7 & 31.41 & & 15.7 & 15.7 & & 15.7 & 7.852 \\
\hline Los Riscos & & 2.416 & 4.832 & & 2.416 & 2.416 & & 2.416 & 1.208 \\
\hline El Judío & & 2.962 & 5.924 & & 2.962 & 2.962 & & 2.962 & 1.481 \\
\hline Coyozochico & & 3.215 & 6.43 & & 3.215 & 3.215 & & 3.215 & 1.607 \\
\hline Karmidas & & 173.5 & 347.1 & & 173.5 & 173.5 & & 173.5 & 86.8 \\
\hline
\end{tabular}

With 1,000 working hours per year, the caves that present an average annual dose below the reference limit are El Judio $(2.962 \mathrm{mSv} / \mathrm{y})$ and Los Riscos $(2.416 \mathrm{mSv} / \mathrm{y})$; the Coyozochico cave presents a value of $3.215 \mathrm{mSv} / \mathrm{y}$ slightly exceeding the reference value.

With 500 working hours per year Karmidas cave still exceeds the reference valuefor workplaces recording an average annual dose value of $86.8 \mathrm{mSv} / \mathrm{y}, 29$ times higher than the $3 \mathrm{mSv} / \mathrm{y}$. Aguacachil and PozasAzules caves present values of slightly higher than the reference value with 3.643 $\mathrm{mSv} / \mathrm{y}$ and $3.596 \mathrm{mSv} / \mathrm{y}$ respectively.

Table 3 shows the number of hours required by an individual in each cave to reach the annual reference level of $3 \mathrm{mSv} / \mathrm{y}$ and the percentage of risk of cancer. These calculations were also done with the "Wise" program [17].

Table 3: Number of hours required for each cave to reach the annual reference dose and the percentage of cancer risk calculated with the program "Wise".

\begin{tabular}{|c|c|c|c|c|}
\hline Cave & $\begin{array}{c}\text { Reference Level } \\
\mathrm{mSv} / \mathrm{y}\end{array}$ & $\begin{array}{c}\text { Hours in the } \\
\text { cave }\end{array}$ & $\begin{array}{c}\text { Annual dose rate } \\
\mathrm{mSv} / \mathrm{y}\end{array}$ & Excess lifetime cancer risk \\
\hline Aguacachil & 3 & 420 & 3.06 & $0.015 \%$ \\
\hline Las Pozas Azules & & 420 & 3.033 & $0.015 \%$ \\
\hline San Jerónimo & & 320 & 3.075 & $0.015 \%$ \\
\hline Gabriel & & 192 & 3.015 & $0.015 \%$ \\
\hline Los Riscos & & 1245 & 3.008 & $0.015 \%$ \\
\hline El Judío & & 1015 & 3.006 & $0.015 \%$ \\
\hline Coyozochico & & 935 & 3.006 & $0.015 \%$ \\
\hline Karmidas & & 17 & 2.95 & $0.015 \%$ \\
\hline
\end{tabular}

A person who enters Karmidas cave requires a stay of just over 17 hours in a day to reach the reference level, or to make 8 tours of approximately two hours each. With the data in table 3 it can be seen that a casual tourist is not exposed to radiological risk when visiting each of the 8 caves. In Gabriel cave are necessary around 192 hours per year to reach the annual reference dose of $3 \mathrm{mSv} / \mathrm{y}$; in San Jeronimo cave the time required to reach the annual reference dose is about 320 hours. Because in Aguacachil cave and Las Pozas Azules the concentration of ${ }^{222} \mathrm{Rn}$ is almost the same, the time to reach the annual reference dose is around 420 hours per year. On the contrary, the guides can make numerous 
tours in these places, and speleologists can even stay there for several days.

In Mexico speleologists and cave guides have a radiological risk associated with their profession that they should be aware of. The doses of environmental radiation they receive during the tours they take in these environments vary from cave to cave and must be measured constantly. Therefore, the use of portable monitors will be of great help in regulating the times of stay and the length of the tour.

\section{Conclusions}

All studied caves have high ${ }^{222} \mathrm{Rn}$ concentration. The doses calculated for each cave with 2,000 working hours per year exceed the recommended doses for workplaces. It is recommended that guides and speleologists routinely use portable radon monitor so they can know the dose of environmental radiation they receive during their tours. Tourists who occasionally visit the eight caves studied and stay a few hours in them will not exceed the recommended annual limit and therefore will not present a radiological risk.

\section{Competing Interests}

The corresponding author declares no conflicting of interests.

\section{Acknowledgments}

This work was partially supported by PAPIIT-DGAPAUNAM project IN102819.

\section{References}

[1] S. Alberigi, B.R.S. Pecequilo, H.A.S. Lobo and M.P. Campos, Radiation Protection Dosimetry 145, 252 (2011). https://doi.org/10.1093/rpd/ncr054

[2] J. Borau, A. Gonzales, G. Espinosa and J.I. Golzarri, Nuclear Tracks and Radiation Measurements 22, 287 (1993).

https://doi.org/10.1016/0969-8078(93)90069-G
[3] A.A Cigna, International Journal of Speleology 34, 1 (2005). https://doi.org/10.5038/1827-806X.34.1.1

[4] J.T. Duffy, J.S. Madden, G.M. Mackin, A.T. McGarry and P.A. Colgan, Environment International 22, 415 (1996). https://doi.org/10.1016/S0160-4120(96)00140-7

[5] G. Espinosa, Radon gas in caves (Original: Gas Radón en Cuevas). (Physics Institute, National Autonomous University of Mexico, Mexico, 2016).

[6] G. Espinosa, J.I. Golzarri, R.E. Gammage, L. SajoBohus, J. Viccon-Pale and M. Signoret-Poillon, Radiation Measurements 43, S364 (2008). https://doi.org/10.1016/j.radmeas.2008.04.033

[7] G. Espinosa, J.I.Golzarri, E. Vega-Orihuela and J.B. Morales-Malacara, Journal of Radioanalytical and Nuclear Chemistry 296, 43 (2013). https://doi.org/10.1007/s10967-012-1975-8

[8] A. Hoffman, J.G. Palacios-Vargas and J.B. MoralesMalacara, Manual of Biospeleology (Original: Manual de Bioespeliología). (National Autonomous University of Mexico, Mexico, 1986).

[9] C.N. Grant, G.C. Lalor and M. Balcazar, Applied Radiation and Isotopes 71, 96 (2012). https://doi.org/10.1016/j.apradiso.2012.07.007

[10] C. Lazcano, Gaceta UNAM. No. 41, 21 (1983).

[11] P. Jovanovič, Environment International 22, 429 (1996). https://doi.org/10.1016/S0160-4120(96)00142-0

[12] W.W. Nazaroff, Reviews of Geophysics 30, 137 (1992). https://doi.org/10.1029/92RG00055

[13] P. Szervin, Environment International 22, 389 (1996). https://doi.org/10.1016/S0160-4120(96)00137-7

[14] F.A.G. Paz, Y.A.G. Romero and R. Zalakeviciute, Journal of Radiation Research 60, 759 (2019). https://doi.org/10.1093/jrr/rrz064

[15] UNSCEAR, Sources and effects of ionizing radiation. (United Nations, New York, 2000).

[16] US-EPA Environments Division (6609 J). US-EPA, Washington, DC (2004).

[17] WISE. http://www.wise-uranium.org/rdcrnh.html. (2009). Accessed 10 Aug 2020. 


\section{Journal of Nuclear Physics, Material Sciences, Radiation and Applications}

Chitkara University, Saraswati Kendra, SCO 160-161, Sector 9-C, Chandigarh, 160009, India

Volume 8, Issue 2

February 2021

ISSN 2321-8649

Copyright: [ $@ 2021$ A. Chavarria, J.I. Golzarri and G. Espinosa] This is an Open Access article published in Journal of Nuclear Physics, Material Sciences, Radiation and Applications (J. Nucl. Phy. Mat. Sci. Rad. A.) by Chitkara University Publications. It is published with a Creative Commons Attribution- CC-BY 4.0 International License. This license permits unrestricted use, distribution, and reproduction in any medium, provided the original author and source are credited. 